Vanacker, V. Frits

1973 Een onnederlandse konstruktie in zuidwestelijke dialekten. Album Willem Pée, 367-377. Tongeren: Michiels.

Vandenberghe, Roxane

1995 Het Frans-Vlaamse Dialect: Morfologische integratie van de Franse lexicale ontleningen en syntactische kenmerken. Unpublished M.A. thesis, University of Ghent.

Vandenberghe, Roxane

1998 Lexicale ontlening uit het Frans in het Frans-Vlaamse dialect en morfologische integratie van de substantieven. In: Actes du colloque de la lère journée de la Coordination Universitaire pour l'Etude du Flamand, Université Catholique de Lille (16 octobre 1998), 73-82. Lille: Université Catholique de Lille.

Van Durme, Luc

2002 Genesis and evolution of the Romance-Germanic language border in Europe. In: Jeanine Treffers-Daller and Roland Willemyns (eds.), Language Contact at the RomanceGermanic Language Border, 9-21. Clevedon/Buffalo/Toronto/Sydney: Multilingual Matters.

Van Goethem, Herman

1987 [1989] Eén volk, éen taal. Nationalisme en taalwetgeving in Frankrijk vanaf 1670, en in de geannexeerde Zuidelijke Nederlanden (1795-1813). Wetenschappelijke Tijdingen 46: 57-86, 129-147. [An adapted French version of this article is: La politique des langues en France, 1670-1804. Revue du Nord: 437-460].

Vanneste, Alex

1972 Taaltoestand in Frans-Vlaanderen. Ons Erfdeel 15(3): 57-59; 15(4): 29-62.

Vanneste, Alex

1982 Le français et le flamand en Flandre française: essai sur le recul de la frontière linguistique. In: Jean Caudmont (ed.), Sprachen in Kontakt - Langues en Contact, 17-35. Tübingen.

Willemyns, Roland

1997 Language shift through erosion: The Case of the French-Flemish "Westhoek". Journal of Multilingual and Multicultural Development 18: 54-66.

Hugo Ryckeboer, Ghent (Belgium)

\title{
42. Between Dutch and Indonesian: Colonial Dutch in time and space
}

1. Introduction

2. Key episodes in the history of Dutch-Indonesian language contact

3. Variation in Indonesian-Dutch language contact

4. Concluding remarks

5. References

\section{Introduction}

This contribution discusses the history, structure and use of mixed language varieties resulting from colonial language contact, from 1600 to the present, between speakers of 
Dutch and of Indonesian/Malay in the former Netherlands Indies (present-day Indonesia).

\subsection{Colonial language contact and the varieties of Indies Dutch}

Language contact "occurs when speakers of different languages interact and their languages influence each other" (Matras 2009). Contact linguistics deals with "any change in a language resulting from the influence of a neighbouring language of which the speakers of the first have some knowledge; the passage of linguistic objects or features from one language to another. The effects of contact may range from the trivial to the overwhelming, and may involve vocabulary, phonology, morphology, syntax or just about anything else" (Trask 2000: 183).

In the 1950s, after Indonesian independence, several hundred thousands of Dutch colonials and Indo-Dutch (mixed-race Eurasian) people with Dutch nationality came to the Netherlands, bringing along speech varieties ranging from near-native SD through so-called 'Indies Dutch' all the way to the heavily mixed forms of Pecok (Van Bree and De Vries 1997, cf. Nieuwenhuis 1930: 5; see further section 3.5. below), spoken by lowerclass Indos in the streets of the former colonial capital Batavia (present-day Jakarta). At the time, this street language was strongly looked down upon, but in an interesting postcolonial turnaround led by the Indo-writer Tjalie Robinson (1911-1974) and his annual Pasar Malam festival (Willems 2008), it is now almost a badge of identity for many Eurasians living in the Netherlands, and in The Hague one can even take courses in it. Even so, these colonial varieties are mostly spoken today by the older generation, who after decades in the Netherlands, especially if they did not have much education, may still speak "an imperfect Dutch interspersed with Javanese and Malay" (Bast 2010: 146). The general pattern, meanwhile, especially amongst the children and grandchildren of those former colonials, has been a shift to SD, encouraged by strong socio-economic pressures towards assimilation in Dutch society (Oostindie 2010).

Yet another colonial contact variety can be found in the "soldiers' Malay" of the more than 125,000 Dutch conscripts involved in the Indonesian decolonization conflict. And then there is the Amboyna Malay ('Melayu sini') spoken by a group of former colonial soldiers from the Moluccas who in 1951 were disbanded in the Netherlands. They and their descendants continue to use this as their in-group language of Moluccan identity, while in the outside world of school and work the language used is Dutch. Malay-Dutch language contact thus continues to be an everyday living reality for this group (Tahitu 1989).

\subsection{Indies Dutch sociolects and their speakers: Key factors in variation}

Variation is the key word here (cf. Den Besten and Hinskens 2005). The varieties of mixed language behaviour which arose in these different colonial contact situations do not constitute a single, homogeneous, stable and well-defined variety of Dutch. Rather, Indies Dutch is a wide-ranging collection of sociolects, "with a large measure of regional, social, historical, structural, stylistic and individual variation. These sociolects can be 


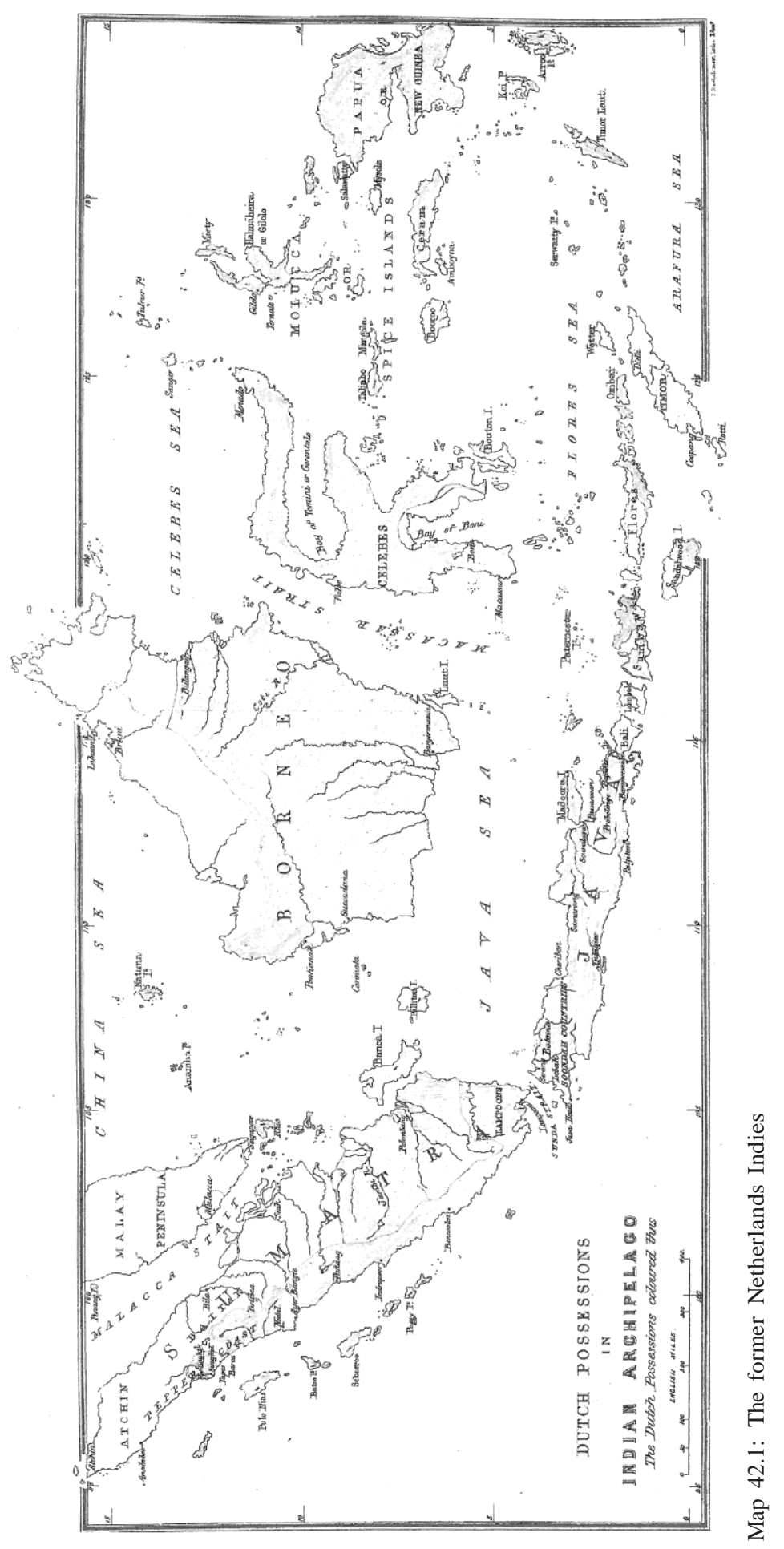


very different and range from a difficult, almost incomprehensible creole based on Dutch and Indonesian to very careful SD, pronounced more carefully than the Dutch of native speakers born in the Netherlands". (Van den Toorn 1995: 1, my translation, RS).

The ex-colonials who came to the Netherlands were a very diverse lot; and the Indies Dutch speech varieties they brought along no less diverse than their personal legal, ethnic, racial or socio-economic status in the former East Indies. How these people in conversation actually mixed their speech, to what extent they combined elements and features from Dutch and Malay, and which linguistic repertoires they developed in the process - in short, what variation they produced -, depended very much on a range of socio-cultural, political and linguistic factors, six of which can be identified here. The first concerns the mother tongue and linguistic background of the speakers involved: were they native speakers of Dutch, Malay, Javanese or Chinese, what was their degree of proficiency in those languages, and which particular varieties of these languages did they actually use in contact? Secondly, what was their position in history: were they employed in the few Dutch trading outposts dotted around the archipelago in the time of the Dutch Republic, did they take part in the Dutch conquest and unification of the archipelago in the course of the nineteenth century, or were they part of the rapidly expanding numbers of Dutch people in the much more settled, urban colonial society just before the end of the Dutch Empire in 1942? Thirdly, it matters in what region the speakers were stationed: in the capital Batavia on Java, or perhaps in the large plantations on Sumatra, or on lonely outposts in the Outer Regions elsewhere in the Archipelago? Cf. Map 42.1, a historical map of the former Netherlands Indies. And how frequent and intense was their contact with those other languages? The fourth factor to be considered has to do with their ethnicity and legal status: were they Dutch-born, or of Dutch descent, or Indonesian, or mixed-race (Eurasian); were they born and bred in the East Indies, or recent newcomers from Europe; and to which of the three legal categories of colonial subjects did they belong: Europeans, Foreign Asians or Natives (cf. Salverda 2009)? A fifth question cuts across this and concerns their social class, education and profession: were they well-to-do and well-educated Dutch and Javanese members of the colonial ruling class, or poor and uneducated lower class people, whether Native, IndoDutch or European? And last but not least, there is the role of the unspoken grammar of colonial culture: what were the language-political attitudes and sensitivities observed by speakers in contact, what communicative repertoire(s) did they employ in conversation, and how did these fit in (or not) to the colonial rules and conventions for social intercourse?

\subsection{Terminology and preview}

A note on terminology is required here. In Dutch we are faced since colonial days with a distinction between 'Indisch', 'Indo' en 'Indonesisch', which I will render here respectively as 'Indies, i.e. colonial', 'Indo, i.e. mixed Eurasian', and 'Indonesian, i.e. including the former colonial categories of Malay (language) and Native (population, nationality)'.

'Indies Dutch' will be used here to refer to all colonial varieties of Dutch from the archipelago, as distinct from native SD as spoken in the Netherlands.

Starting from this initial overview we will now first take a look at the historical background to these varieties of Dutch-Indonesian language contact. Secondly, we will 
look into the key linguistic features and contact processes involved. By way of conclusion we will identify a number of desiderata for further research of Indies Dutch variation. The bibliography, finally, brings together publications, especially of the last two decades, which make significant contributions to further study.

\section{Key episodes in the history of Dutch-Indonesian language contact}

\subsection{Indies Dutch: A forgotten colonial language}

In the Netherlands today, Indies Dutch is spoken only in private conversation, as the ingroup language of the older generation of Indos (De Vries 1994b). So too in Indonesia, it is only in the older generation that one may still encounter speakers of Dutch. Indonesian archives contain many miles of documents in Dutch, but there is in Indonesia today no Dutch-speaking middle class. This is in great contrast to the situation of English in India today. To understand this, we will have to take a look at the interaction between Dutch and Indonesian in colonial history (in section 2.). But first we will consider the existing tradition of scholarship on the subject.

In the field of Dutch-Indonesian language contact and variation we are fortunate to have the indispensable older studies by Prick van Wely, Van Ginneken, Kalff, Nieuwenhuis, De Geus and Van Dam, as well as the scholarly articles by Van den Toorn, and the work of Tjalie Robinson. In general, however, it must be said that Dutch linguists have paid far less attention to these colonial varieties than to the dialectal and social varieties of Dutch as spoken in the mother country. Dutch creolists, too, have paid far less attention to the Indonesian varieties of Dutch than to the linguistic systems which developed in other Dutch colonies, such as Afrikaans and Negerhollands. Unlike Schuchardt's Malayo-Portuguese, Dutch-Indonesian contact varieties do not figure on the world creole list and we do not have a thorough, systematic social and linguistic study of Indies Dutch like the monograph on colonial North African French by Lanly (1970) or the analysis by Trudgill (1986) of contact varieties in Colonial English.

Part of the explanation for this state of affairs is related to colonial attitudes and mentalities. In the course of colonial history, as we learn from the studies mentioned above, the language of the Indos - or liplappen ('chee-chee, métis') and blauwen ('babba, half-caste') as they were often nicknamed - has always attracted strong social disapproval as well as ethnic and racial prejudice (cf. Cleintuar 1971). This has seriously hampered scholarly research. Thus, for example, the leading Dutch linguist Van Ginneken could ask in 1913: "What interest could such gibberish possibly have for a civilized Dutchman? What nonsense to print such terrible stupidities in a serious book. Moreover, wouldn't this be propaganda for those mongrel languages? Really, it would only be fitting to keep quiet about such things." (Van Ginneken 1913, I: 324, my translation, RS). But despite such prejudice, there has also been a clear awareness of the scholarly importance of studying this colonial language variation, and the same Van Ginneken wrote: "The scholarly point of view is the one adopted by the linguist who wants to study the deepest causes of the changes, variations and differences between languages 
and dialects. In this respect, a little mongrel lingo is welcome material just as much as the most refined literary idiom." (Van Ginneken 1913, I: 324, my translation, RS).

It was only well after the colonial era that the situation began to change. In the 1980s, in the popular TV cabaret The Late Late Lien Show of Wieteke van Dort, the Indies variety of Dutch was used for the symbolic construction of a cultural identity for this ex-colonial community (cf. Kortendick 1996, Van Leeuwen 2008). And over the past two decades there has been a growing interest in the subject, witness the stimulating publications by De Vries, Giesbers, Groeneboer, De Gruiter, Kortendick, Tahitu, 't Hart and Van Rheeden.

\subsection{Lingua franca Malay versus Dutch as the language of Empire}

When the Dutch first arrived in the East Indies in 1596, Malay was already the spoken lingua franca all around the archipelago, an area larger than Europe and more diverse in languages, cultures and religions. Malay, 'the Italian of the East', was deemed easy to learn and very useful as an intermediary for trade and communication with the local people. Learning Malay was also a necessity for the Dutch, given their small numbers in the Indonesian archipelago: by 1795 there were no more than 543 Dutchmen living in Batavia, amidst a very large mestizo community speaking mostly Malay and Portuguese. In the course of the nineteenth and twentieth centuries, the Dutch increased in number, but they always remained a minority. Dutch was the language of power and of the ruling class; but it never became the most widespread nor the most widely used language.

In British India, in 1835, at the instigation of the colonial politician Thomas Babington Macaulay (1800-1859), the decision had been taken to introduce English language education at all levels, thus opening up western culture and knowledge for the Indians. The Dutch, however, made a very different decision when building up their empire in the East Indies. Their colonial language policy started from an acceptance of the fact that Malay alone was the lingua franca that was used everywhere, and in 1864 it was decided to disseminate this language - and not Dutch - throughout the colony. This policy was motivated by financial considerations as much as by the idea that Dutch would be too difficult for the Indonesian natives, and also by the fear that the Dutch language, as 'gateway to the west', might bring all kinds of dangerous western ideas to the archipelago - since, surely, once the natives could read Dutch, they would not confine themselves to reading harmless books (Groeneboer 1998a). This Dutch decision has produced one of the most intriguing chapters in the history of Dutch colonial cultural and language policy in the East Indies. As Malay was to be the vehicle for the unification and modernization of the archipelago, so the colonial government stimulated the study of this language; regulated and standardized its spelling, dictionary and grammar; westernized its appearance and modernized its use by changing from Arabic to Latin script; and, during the first decades of the twentieth century, imposed this 'government Malay' via its institutions, via the schools, the missions and the media, and via the many Malay translations and literary works produced and disseminated by the state publishing office, Kantoor voor de Volkslectuur (Jedamski 1997, Maier 1997).

At the same time, Dutch language education was deliberately kept for the Dutch and for the happy few amongst the indigenous elite. By restricting access to Dutch language schools, the colonial authorities were effectively defending the position of their language as the language of power vis-à-vis all other languages. Its privileged position was further 
underpinned by a range of deep-seated colonial attitudes concerning the purity and status of the language. For, as we know from an 1890 government circular, many Dutchmen in the colonial civil service found it completely unacceptable if an Indonesian native dared to address them in Dutch instead of Malay (Groeneboer 1998a: 140). Thus, while their numbers stayed low - in 1893, there were no more than 9000 Europeans residing in Batavia, amidst 2800 Arabs, 26,000 Chinese and 72,000 Natives (Castles 1967: 157) the Dutch language by and large remained the property (and power symbol) of the predominantly white European colonial ruling class.

Meanwhile, from the middle of the nineteenth century there was a slowly growing recognition on the part of the colonial authorities of the desperate existence of the numerous 'pauperized' lower class Europeans and their mixed-race children living at the margins of colonial society (De Braconier 1919, Cleintuar 1971). Since knowing Dutch certainly was a career advantage, quite a lot of effort was put into providing these children with an education in Dutch. In the process, however, they were expected simply to shift away from their own uneducated Indo-Dutch as spoken at home, towards the native SD of the schools. This was in keeping with the so-called 'principle of concordance' in Dutch colonial law, which aimed to ensure equivalence with standards from the motherland (cf. Salverda 2009: 159). Thus, until the 1920s and 1930s the colonial education system made no allowance for the fact that these children were not native speakers of Dutch, or the idea that their education might actually benefit from the principles developed in foreign and second language learning (Nieuwenhuis 1930). Instead, the large majority of Europeans throughout the period always considered 'the struggle against Indo-Dutch' as the greatest and most persistent problem facing Dutch language education in the colony (Groeneboer 1998a: 153).

\subsection{Dutch, Indies Dutch and Indonesian: competition, conflict and defeat}

Dutch East Indies colonial society in the twentieth century had a markedly hierarchical character, with the population segregated into three major categories. In the European upper layer, which by 1930 had grown to some 190,000 people, Dutch was dominant, over and above other languages such as English, French, German, Italian and Japanese. In Native society, by 1930 the largest category of the population with 60 million people, Malay was used as the lingua franca, alongside many other indigenous languages such as Sundanese, Javanese or Madurese. In between, in the third category of colonial subjects, the so-called Foreign Asians, a host of other languages were spoken, in particular Chinese, English and Arabic, but also Indian languages such as Gujarati, Hindi and Punjabi.

Multilingualism thus was an everyday reality in the Netherlands Indies. Within each of the three population categories different languages were spoken, while in between, in contact and communication between speakers from these different communities, people would commonly use the general lingua franca, Malay, or else Dutch, often in a local variety of a more or less mixed character. In Batavia, for example, there always was the Indies variety of Dutch; plus the heavily mixed, very low status Pecok as spoken by the pauperized mixed-race Indos of city districts like Kemajoran, Karangbidara and Krambangan (De Geus and Van Dam 1935: 4); as well as the street Malay or Bahasa 
Betawi (Chaer 1982, Grijns 1991, 1998) spoken by the local natives. Elsewhere, for example in the city of Semarang in Central Java, the street lingo was a mix of Dutch and Javanese known as Javindo (De Gruiter 1990, 1994).

In this multilingual context, Dutch language education was traditionally aimed at the children of the European governing class and their Indonesian associates. To widen the support base for Dutch, in the 1930s colonial educationalist such as Brugmans and Nieuwenhuis were actively promoting the large-scale teaching of Dutch across the Indonesian archipelago, and by 1940 Dutch speakers numbered about two percent of the total population (Groeneboer 1998a). The linguistic norm for these Dutch speakers always remained the mother tongue as spoken by its native speakers in the Netherlands. There always was an "immense pressure on the Indies community to conform to the model of the Dutchman born and bred in the Netherlands" (Kousbroek 1992: 217), and creolized varieties of Indo-Dutch met with a sustained social and educational backlash, with a strong emphasis on correcting the so-called 'Indische fouten' ('Indies errors', cf. De Geus and Van Dam 1935). The education authorities in the Netherlands Indies, again because of the principle of concordance, also strictly maintained the old-fashioned Dutch orthography of 1863 , and consistently dismissed proposals to simplify its arcane intricacies for the benefit of the many colonial learners of the language (Daman 1941).

The rapid growth in numbers of the Dutch-speaking community between 1900 and 1930 also entailed an increasing competition between Dutch, Indonesian and Indies Dutch. And because of the colonial mentalities and attitudes involved, such language issues acquired great symbolic power and socio-political significance. For example, in the 1920s a colonial Dutchman could still put down an educated, Dutch-speaking Indonesian conversation partner by addressing him not in Dutch but in Malay - in other words, as a Native (Salverda 1994a). Beyond such symbolic confrontations, what mattered from a sociological point of view was the linguistic dilemma in the Netherlands Indies, when - as De Swaan (2001) has observed - for the large majority of the population the Dutch language usually was only their third choice. That is, even if Dutch at the time still was the language of power, Malay clearly was the most widely used and the most useful language (cf. Salverda 1994a, b, Grijns 1998).

Things came to a head in the late 1920s, when rising Indonesian nationalism was faced with heavy political repression. In reaction, in 1928 the Indonesian Nationalist Movement united behind the Sumpah Pemuda or Youth Pledge, the rallying cry of 'One country, one people, one language', with the Indonesian language as the symbolic expression of their national identity and political aspirations (Sneddon 2003). This was a key moment in colonial history, when young Indonesians united against the Dutch and their language, which thus became the symbol of colonialism - as later on, Afrikaans was to become the symbol of Apartheid. So when Indonesian independence came in 1945, Dutch was quickly abolished and replaced by Bahasa Indonesia as the official language of the Indonesian Republic.

\section{Variation in Indonesian-Dutch language contact}

\subsection{Languages in contact: Processes and outcomes}

In this section we will explore the contact-linguistic processes through which those colonial language varieties arose - focusing first (in section 3.2.) on lexical contact and 
exchange; then, secondly (in 3.3.), on the sound shape of Indies Dutch; thirdly (in 3.4.), on its morphosyntactic structure; and finally (in 3.5.), on the special case of Pecok. The closing section (3.6.) will present an analytic overview of the different varieties within Indies Dutch.

Our opening question concerns the link between social and linguistic variation within Indies-Dutch. In the plurilingual colonial society of the Netherlands Indies, speakers of Dutch used to live and work in close contact with speakers of Malay and other languages such as Javanese, Sundanese, Chinese, Arabic, etc. In, for and through that contact, many people developed multilingual skills and repertoires, employing these as required by the social, cultural or linguistic demands of the situation. And as they mixed, so did their languages. So, our first concern here must be to establish which particular varieties of language (and which speakers) were in everyday contact with each other. In colonial times, Dutch-Indonesian language contact was dominated for centuries not by the stan-dard-Dutch and the standard-Indonesian/Malay of today, with their massive state sup- port, written standard and educational advantages, but by the informal spoken varieties of pidginized Bazar Malay and the street language spoken by Dutch sailors and soldiers.

Our next concern will be to explore what exactly happened in this contact. Which contact processes were involved and how did these work out? What linguistic features and elements were transferred from one language to the other, and through which processes of contact and influence? The linguistic contact behaviour we will be looking at here ranges from what used to be called 'bastardization' and folk etymology, via pidginization and creolization, through borrowing, transfer, translation, adaptation and transformation to the emergence of new forms of language and new linguistic repertoires, including social and linguistic practices such as code switching and language mixing (cf. Matras 2009).

As a result, different mixes of Dutch and Malay arose, each with their specific structure, use and social significance. Depending on what the mother tongue of a speaker was, one could end up closer to Malay, speaking 'Dutch in an Indonesian mouth' (De Vries 1994a: 32), or nearer to Dutch and speaking 'Malay in a Dutch mouth'. So our third concern will be to explore whether and how to account for these contact varieties in a diasystem between Malay and Dutch.

Our fourth and final concern will - eventually - be to explore what explanatory perspectives may serve to understand the multilingual repertoires underlying the contact varieties we encounter in Indies Dutch (cf. Matras 2009). A good first candidate here would appear to be the process of mixed languages developing and fossilizing in spontaneous, unstructured and untutored second language learning in the streets (Van Rheeden 1994a: 235).

\subsection{Words and their histories: Indonesian-Dutch lexical contact and adaptation}

In this section we will concentrate on matters of meaning and use, leaving the way in which these Malay words were adapted to the Dutch tongue for section 3.3. below.

The history of colonial language contact in Indonesia has left many interesting lexical traces in the languages involved, in a two-way process affecting both Dutch and Malay. 
While Dutch has adopted some 500 words from Malay (Van der Sijs 2005), the Indonesian language has borrowed ten times more from Dutch. In Indonesian today, we find Dutch loanwords in everyday use, such as the rekening ('bill') in a restoran ('restaurant'), or the karcis ('tickets') for the bioskop ('cinema'), alongside words for butter, soap, church and school (mentega, sabun, gereja and sekolah) which have come from Portuguese. Here, as documented in the etymological dictionary of Jones (2007), Malay demonstrates a key feature of lingua francas: the easy incorporation of both loanwords and grammatical borrowings (cf. Tadmor 2007) from many other languages such as Arabic, Chinese, Dutch, English, Hindi, Japanese, Latin, Persian, Portuguese, Sanskrit and Tamil.

A similar historical-etymological dictionary of colonial Dutch would have to deal with Malay loanwords such as bakkeleien ( $<$ Indonesian berkelahi, 'brawl'), pienter ( $<$ Indonesian pintar, 'intelligent'), soebatten (< Indonesian, sobat, 'to plead'), or with moesjawara, a well-known Malay term used for the long-drawn out, consensus-oriented palavers that were customary in Dutch politics in The Hague. However, the lexicographic and cultural-historical complexities facing such an investigation are immense, as Den Besten's (1992) study of colonial loanwords such as zuurzak (< Malay sirsak, 'soursop') and rotting (< Malay rattan, 'walking stick of rattan') has shown. The Indisch Lexicon by Mingaars et al. (2005) offers lots of information on such Malay loanwords, often with quotes from Indies Dutch colonial literature. But its selection is rather haphazard, and does not provide the historical and etymological detail we find in the older but still invaluable dictionary of colonial Dutch by Prick van Wely (1910). A better starting point is the survey of Dutch loanwords from Indonesian in the Groot Leenwoordenboek (2005) by Van der Sijs. As she demonstrates, language contact constantly generates variation, through changes in the vocabulary, transformations of the sound shape, and shifts in the meanings and uses of the words involved (not to mention shifts in the underlying mentalities and attitudes).

With respect to these shifts and changes 't Hart (1998) has demonstrated how Malay loanwords often acquired new meanings when incorporated into Indies Dutch, through reallocation processes (cf. Trudgill 1986) such as generalization (Dutch amok maken ('to cause trouble') versus the more specific Malay amok ('run wild and kill people'); restriction (specific Dutch passagieren ('shore leave') versus general Malay pesisir ('coast'); and semantic shift or even quantifier reversal (Dutch amper ('hardly, almost not') versus Malay hampir ('almost'). New colonial words also came about as a result of loan translation - as in jongen (meaning 'male domestic servant') from colonial English boy; and aankeren ('to drop in, call at someone's house') from Malay mampir.

What 't Hart also demonstrated was how Malay loanwords often acquired negative, even pejorative new meanings, as for example in Dutch negorij ('the back of beyond') versus Malay negeri ('country'), and piekeren (Dutch tobben, 'worry') versus Malay pikir ('think'). This is in fact a much wider phenomenon, which appears to be typical of colonial relations in the lexical field. Thus, Indies Dutch njai, meaning 'Native concubine, maîtresse indigène, kept woman, Haushälterin' (Prick van Wely 1910: 156-157) is some way off its original meaning in Malay and Javanese, where nyai is an honorific for an unmarried and independent young woman. Such naming processes were never neutral, as we can see in the case of Dutch plopper, an insulting label for an Indonesian person - a usage dating back to the Dutch soldiers' Malay during the Indonesian war of independence of the late 1940s - whereas its Malay source, pelopor, actually derived 
from Dutch voorloper ('forerunner') and had quite a positive meaning, viz. 'pioneer' or even 'revolutionary fighter'. Such nicknaming practices appear to have been part and parcel of colonial language contact.

However, loanwords and borrowing processes are only one part of the story. Colonial vocabulary in the Indies also grew and expanded through new formations within Dutch itself. Over the centuries the Dutch in the East coined a large new colonial vocabulary that was different from general Dutch, with words such as rijstchristenen ('rice-Christians, i.e. occupationless incapables who join the church for revenue only' - 'the white colonists' nickname for the product of Protestant missionary work', cf. Mark Twain 1897: 447-448), and handschoentje (literally 'little glove'), a Dutch bride whose wedding to a Dutchman in the East Indies was concluded by proxy in the Netherlands before she would sail out to be united with him in person (cf. De Vries 2005). There is currently no comprehensive and systematic description available of this colonial vocabulary of Indies Dutch. It is not included in Van der Sijs (2005) nor in the recent Dutch-Indonesian dictionary of Moeimam and Steinhauer (2004), which is restricted to the two modern standard languages of today.

This neglect of the colonial vocabulary of Indies Dutch can have peculiar consequences. In the legal field, for example, a vast collection exists of Dutch colonial terms for all kinds of legal situations in the former East Indies, such as breidel ('censorship'), erkenning ('recognition', usually of mixed race children by their European father), exorbitante rechten ('extraordinary powers of the Dutch governor-general to have anyone arrested, imprisoned or banned without involvement of the courts'), godsdienstige rechtspraak ('religious jurisdiction'), haatzaai ('sowing hatred'), landraad ('local district court, mostly for Natives'), voorkinderen ('children from a previous relationship, usually with a native concubine') and vrijwillige onderwerping ('voluntary subjection of a Native to European law'). But these legal terms are generally unknown in the Netherlands. Here, colonial etymology will have to be complemented by a critical postcolonial discourse analysis of their socio-political uses and connotations if we are to achieve a proper understanding of a word like haatzaai or even the name Indonesia, which was forbidden in colonial days (cf. Salverda 2009: 156-157).

\subsection{The sound shape of Indies Dutch: Adaptation and transformation}

The first thing we need here is a solid and representative corpus of spoken Indies Dutch contact varieties, as the basis for a proper phonetic and phonological investigation of the Indies accent. Once this corpus is in place, the focus of investigation should be on the pronunciation of Indies Dutch in relation to the social range of its variation. As we saw above, there has always been the strong Dutch native speaker norm, as a result of which one can, amongst the older generation of Indonesian speakers of Dutch, still hear very careful, almost-standard Dutch, pronounced more carefully than even the Dutch of native speakers born in the Netherlands, often with spelling pronunciations like wraak ('revenge') with a bilabial [w], instead of [vra[k] (Van den Toorn 1995: 1).

But many people never went to school, and school was not the main theatre of language contact. Also, the varieties in contact were not the modern Dutch and Indonesian standard-languages, but rather the everyday informal street varieties then in use. This is particularly evident in the contact-induced adaptation of Dutch loanwords to the sound 
patterns of Indonesian, as in the dialect of Jakarta, Bahasa Betawi (cf. Chaer 1982, Muhajir 1984): reduction of consonant clusters through t-drop (Malay orkes < Dutch orkest ('orchestra')), s-drop (Malay on < Dutch ons, 'ounce') and schwa insertion (Indies Dutch erreg < Dutch erg 'very'); simplification and reduction of the voiced/unvoiced opposition in Dutch [f/v] to [p] (Indies open < Dutch oven 'oven'); adaptation of vowels through shift of long Dutch [o[] to short [o] (Malay om < Dutch oom 'uncle'), long [e[] to short [1] (Malay onderdil < Dutch onderdeel 'part') and long diphthong through unrounding and monophthongization to short $[\varepsilon]$ Malay letnan $<$ Dutch luitenant 'lieutenant').

Interestingly, the effect of these Malay sound changes can also be found in speakers of Indies Dutch and Pecok, setting them and their Malay-accented varieties of Dutch clearly apart from Dutch native speakers. As was shown on The Late Late Lien Show, certain pronunciation features are immediate markers of an Indies accent, such as the use of the fully stressed forms of the Dutch pronouns hij, jou, mij instead of the reduced forms $i e, j e, m e$, giving Indies $i k$ vergis mij, where SD usually has $i k$ vergis me (i.e. 'my mistake'); the formation of questions by adding $J a$ with rising intonation at the end of a declarative main clause, producing a question like $I k$ heb altijd gelijk ja? ('I am always right, yeah?'); and the rolled dental [ $r$ ] from Malay, as in Indies jawel menirr (from Dutch ja meneer, 'yes sirrah'). Here again, we may note that these pronunciation markers of Indies speech have often been used for colonial mimicking, parroting and stereotyping.

\subsection{The mixed morphosyntax of Indies Dutch}

In the domain of morphosyntax, Indonesian-Dutch language contact has given rise to phenomena characteristic of mixed syntax, where structural elements or features from two or more different languages can be combined within a single new utterance (cf. Salverda 1997). Syntactically, Dutch as a Germanic language - in contrast to Malay/ Indonesian as an Austronesian language - is a Subject-Predicate-language with obligatory copula and inflection; with obligatory Verb Second in declarative main clauses (alongside more flexible word order arrangements in different sentence types); and with dominant Modifier-Head-order within the word group. The Indonesian language, on the other hand, is a Topic-Focus-language without obligatory copula or inflection; it is a Subject-Verb-Object language like English or French, i.e. without Verb Second-requirement and without word order differences between main and subordinate clause; and with Head-Modifier-order in the nominal word group, as in Indonesian kantor pos which is the reverse of Dutch postkantoor ('post office').

In Indies Dutch, features from Dutch and Indonesian syntax may be combined in varying ways. Malay loanwords in Indies Dutch usually acquire Dutch inflection, witness verb forms such as tandakken (Dutch infinitive ending in -en from Indonesian root tandak, 'dance'), gesambeld (Dutch past participle frame $g e-\ldots-d$ containing Indonesian root sambal, 'chili pepper'), ngopi-end (Dutch present participle ending in -end after Indonesian verbal root ngopi, 'drinking coffee'); noun forms such as een makannannetje (Dutch noun group with article een, 'an', plus diminutive ending -etje attached to Indonesian root makanan, 'food/dish'), betja $=s$ (Dutch plural noun ending in $-s$ from Indonesian root betja, 'rickshaw'), gekipas (Dutch durative process noun with prefix ge- followed by Indonesian verbal root kipas, 'to fan'); or an adjective like bilikken (Dutch 
material adjective ending in -en from Indonesian root bilik, 'rattan mat'). This morphological dutchification of Malay loanwords makes them easier to fit into the Dutch sentence under construction.

How this works out at the sentence level, we can see in the following example taken from the colonial novel Goena-goena by Ceasar Kijdsmeir, published in Batavia in 1930 (cf. Salverda 1994a):

(1) Kijk - zeide ze - met deze kaartjes ik voorspel jou ... onfeilbaar deze, Look - said she - with these cards I predict you ... infallible this,

de kaart hij ziet toekomst en verleden en vertelt aan jou van hoe the card he sees future and past and tells you of how

'Look, she said, with these cards I will foretell you ... this never fails, the card can see future and past, and will tell you how things will go'

This example consists completely of Dutch words, it contains no Indonesian particles and exclamations, no loan translations, and no switches from Dutch into Indonesian or vice versa; yet at the same time sentence (1) clearly exhibits a number of Indonesian syntactic features: O-S-V-word order after preposed met deze kaartjes, where Dutch as a Verb Second-language normally requires inversion (O-V-S); expressive fronting of the predicate plus absence of copula in onfeilbaar deze; and prolepsis of the subject de kaart followed by a sentence with the resumptive pronoun hij.

So, clearly, this is a Dutch sentence, although with strong admixture of structural syntactic features from Malay. It is the presence of these Malay features that mark (1) as a specimen of the Indies colonial dialect of Dutch. As De Vries (1994a) put it, this really is Dutch in a Malay mouth. But it is definitely not Pecok.

\subsection{The special case of the Pecok ethnolect}

Beyond the general Indies Dutch we discussed above, with its characteristic lexicon, sound shape and morphosyntax, there are a number of much more heavily mixed language varieties that are well worth an investigation, such as the Pecok of Batavia (Robinson 1975) which we will consider here in particular, noting that quite similar contact and adaptation processes occur in other such mixed formations which we cannot go into here: the Depok language (De Vries 1976), the secret mixed language of Jakarta street transvestites (De Vries 1989), Javindo, the Dutch-Javanese mixed language of Semarang (De Gruiter 1994), and the mixed languages of the colonial barracks and the orphanage (Van Rheeden 1998, 1999).

The politics of this case begins as soon as we consider its name, Pecok, which according to Van Dale's Dutch Dictionary (1984) was a colonial invective for the lowest category of Indos in Batavia, hence also for the language they spoke (Riyanto 1996: 410). As Tjalie Robinson put it, prejudice and condemnation have always prevented a proper analysis of this street lingo, and with the humorous dialogues in Pecok in his $I k$ en Bentiet (Robinson 1975) - on a par with the playful use of Yiddish and English in Leo Rosten's immortal The Education of Hyman Kaplan (1937) - Robinson aimed to set this right. The language in Ik en Bentiet has a strongly oral quality and contains many expres- 
sive particles and intonational markers of syntactic structure which are typical of spoken Malay. At the same time, more than $80 \%$ of its vocabulary is of Dutch origin, especially the nouns and verbs, which usually exhibit reduced Dutch inflection plus a corresponding increase in Indonesian affixes, for example in tafelblad-nja, a nominal construction with the Indonesian suffix -nja attached to the Dutch noun tafelblad ('table top'); or a verbal construction like di-potret ('to be portrayed, to have one's portrait taken'), where $d i$ - is an Indonesian passive marker attached to the Dutch root potret ( $<$ portret 'portrait'). Such mixed constructions of a Dutch root with Indonesian morphology are quite common in Pecok, far more so than in general Indies Dutch, where we usually encounter Malay roots with Dutch inflection.

The sentence structure of Pecok is even more strongly Malay in character. Over and above the general Indies features of the preceding section, we find in Pecok expressive reduplications borrowed from Malay (lopen-lopen); deletion of topic and subject when these are known and can be retrieved from the context; and lexicalized time reference, with Dutch $a l$ as a loan translation for Malay sudah ('enough already'). A representative example of Pecok is the following from Tjalie Robinson's Piekerans van een straatslijper, published in Bandung in 1952 (cf. Salverda 1997):

(2) "Seh, Tjalie, ik ben weer behandel! Tjoba je kijk deze watch. Drie "Hey Charlie, I been traded again! Tjoba you look this Rolex. Three

hong ik betaal, drie hong, heloof je! Ondertussen defek nummer een, hong I pay, three hong, you believe! Meantime kaputt number one,

tjap lojang nummer twee en soedah, ampoen. Andjing die fen!" Chinese fake number two and wah, too much! What a dog that man!"

'Say, Charlie, I have been duped again! Here, look at this watch. Three hundred I have paid, three hundred, can you believe it! But first of all, the thing is broken, secondly it is a fake, and oh, enough already! What a dog that guy is!'

The mixed character of this passage stands out. Indonesian, Chinese, and English words are combined with Dutch words, which constitute the majority, whereas its sentence structure is strongly dominated by Malay/Indonesian elements and cannot be understood without a knowledge of Indonesian: behandel is a non-existent Dutch word, a loan translation constructed on the Indonesian model of a passive marker (be-) plus a verbal root (< di-dagang, 'been traded', 'deceived'); tjoba is a directive, sentence-forming particle ('Look here!') from Indonesian; Drie hong ik betaal has emotional object fronting together with Indonesian O-S-V word order; defek (from Dutch defect 'defective') and heloof (from Dutch geloof 'believe') exhibit Indonesian phonology; and the end is a highly expressive Indonesian exclamation: Soedah, ampoen ('enough already, I give up'). These Malay features are dominant and there is a concomitant absence of Dutch morphosyntactic features: no inflection, no inversion or Verb Second, and no subordination, only juxtaposition. The closing three-word sentence has a completely Indonesian structure, with emotional fronting of the predicate Andjing (the invective ' $\mathrm{dog}=$ ), absence of copula, and a final, dismissive Indies Dutch subject, die fen ( < Dutch die vent, "that guy').

On account of Pecok data like these, Riyanto (1996: 417) has asked whether this is a variety of Dutch, or of Malay. The same question was asked by De Vries (1994a), and his finding was that the Pecok of the street urchins in Robinson's Ik en Bentiet constitutes 
a mixed language, with a lexicon that is largely Dutch, and a grammar that is strongly Indonesian in character (structural features from Indonesian such as topic- and subjectdrop, or copula-drop, are normally not allowed in Dutch). Likewise, Van Rheeden (1994) analyses Pecok as a spoken mix combining a predominantly Dutch vocabulary with pidgin-Malay morphosyntax. For Riyanto (1996: 412) too, this is a mixed language which takes its grammatical structure from Malay as spoken by the Native mother, and its lexicon and lexical structure from Dutch, the language of the European father.

In the Javindo of Semarang we find similar mixed formations. For example Lho als sommen itu perkara ketjil; als jij snapnul hier tak makenké ('Nah, those sums, no big deal; if you don't get them, I'll do them for you'), which may contain Dutch words such as als, jij, sommen, hier, snap(-pen), nul en maken, yet cannot be understood without a knowledge of its Javanese words and dominant grammatical structure (cf. De Gruiter 1990: 33-34).

Similarly, the Pecok in (2) is not Dutch, since without some knowledge of Malay one couldn't understand it. Yet, conversely, it is not Malay either, for one definitely also needs to know Dutch in order to make sense of it. That is, the Pecok of Batavia was a linguistic system sui generis, a mixed local ethnolect with a consistent and unique collection of features taken from both pidgin Bazar Malay and spoken Dutch, a street lingo acquired by its Indo-speakers without formal, structured language teaching or the support of a written standard.

\subsection{The varieties of Indies Dutch: Structures and usage}

The final question that concerns us here is how the different types of language mixing we have seen related to each other in colonial society.

In an exploration of colonial language variation in Batavia in the 1930s (Salverda 1994a, b) we have managed to identify a number of different intermediate stages in language mixing between Dutch and Indonesian, ranging from very lightly to very heavily mixed. Each of these exhibits a characteristic set of social and structural features, which we can describe as an ordered series moving away from Dutch at the left through a decreasing number of Dutch features plus a concomitant increase in Indonesian features to the Indonesian language on the right. That is, between Dutch and Indonesian we have the following distinctive varieties of language mixing which served a communicative function in colonial society:

Tab. 42.1: Mixed varieties in use in Indonesian-Dutch language contact

\begin{tabular}{lcccc}
\hline Dutch & Light & Heavy & Pecok & Indonesian \\
\hline Verb Second & + & - & - & - \\
Inversion & + & - & - & - \\
Copula & + & - & - & - \\
Dutch inflection & + & + & + & - \\
Dutch lexicon & + & + & + & - \\
Emphatic PRO & - & - & + & + \\
Indon. Morphology & - & - & + & + \\
Topic-deletion & - & - & + \\
Indon. Particles & - & & & + \\
\hline
\end{tabular}


The co-existence of these different varieties facilitated the emergence of new forms of language behaviour and new linguistic repertoires, including options such as mixing and code switching. As Giesbers (1995a; 1995b) has shown, such mixing and switching behaviour enabled speakers to adapt their speech and choose the language option that would best suit the context, addressee, topic or pragmatics of the situation.

So who were the speakers of these different language varieties, and how did they use these in their linguistic repertoires? Below, I have drawn up a sociolinguistic diagram of the languages used in colonial Batavia in the 1930s, detailing who spoke what variety of language:

Tab. 42.2: Who spoke what variety of language in colonial Batavia in the 1930s?

\begin{tabular}{|c|c|c|c|c|c|}
\hline $\begin{array}{l}\text { Population } \\
\text { Category }\end{array}$ & Occupation/Profession & $\begin{array}{l}\text { Speaks } \\
\text { Dutch }\end{array}$ & $\begin{array}{l}\text { Speaks } \\
\text { Malay }\end{array}$ & $\begin{array}{l}\text { Speaks } \\
\text { Indies-Dutch }\end{array}$ & $\begin{array}{l}\text { Speaks } \\
\text { Pecok }\end{array}$ \\
\hline Europeans & $\begin{array}{l}\text { doctor, manager, } \\
\text { police officer }\end{array}$ & + & + & - & - \\
\hline \multirow[t]{3}{*}{ Indos } & $\begin{array}{l}\text { well to do \& } \\
\text { well-educated }\end{array}$ & + & + & + & - \\
\hline & lower clerks & $+/-$ & + & + & - \\
\hline & paupers & - & + & $+1-$ & + \\
\hline \multirow[t]{2}{*}{ Natives } & $\begin{array}{l}\text { servant, office boy, } \\
\text { taxi driver }\end{array}$ & - & + & - & + \\
\hline & street hookers & + & + & - & + \\
\hline Chinese & tradesmen & - & + & - & + \\
\hline
\end{tabular}

It is interesting to see how this reflects the social and conversational conventions that obtained at the time. Malay clearly was the all-purpose medium of communication used by everyone, regardless of the population category one belonged to. None of the other language varieties had such wide distribution and usefulness. At the same time, it is the Indo group which had the widest range of options in its linguistic repertoire. Those Indos who could speak Dutch, Malay and Indies Dutch as well as Pecok (Van Rheeden 1994: 46) were the most versatile group, witness the case of Tjalie Robinson, who, as a fluent speaker of all four varieties, used them to great literary effect in his stories and novels, knowing exactly how, when, where and with whom to mix his speech or to switch from one to the other variety, thereby creatively crossing language borders that would normally be strictly observed and enforced in colonial society.

\section{Concluding remarks}

\subsection{Findings}

This exploration of variation arising from Dutch-Indonesian colonial language contact in the former Netherlands Indies (present-day Indonesia) has focused in particular on 
the question of which types of language mixing were communicatively significant in colonial society. We have identified a number of colonial language varieties, each with their own characteristic mix of linguistic, communicative and social properties, and have situated these on a continuous scale between Dutch and Indonesian.

An integrated investigation such as the one undertaken here, of the enormous variation that can result from language contact, and in particular of the interaction of the social-communicative and structural features of variation in colonial Indies Dutch, and of the mixing of these features in actual linguistic behaviour, is in my view a necessary first step towards an understanding of the formation and use of these mixed languages.

\subsection{Desiderata for further research}

The further study of Indies Dutch language variation will benefit from a realization of the following three desiderata.

First, given the scattered and fragmented state of information and the shortage of representative and reliable language data, it would be extremely useful to build up, while we still can, a digital language database of Indies Dutch and its oral and written varieties, including materials from the Oral History project of Heather Sutherland, the Centrum '40-'45, the Pasar Malam cultural festival, the Late Late Lien Show, Indo-magazines like TongTong and Moesson as well as Indies Dutch colonial literature. Once this corpus is in place, we will be in a much better position to pursue the various issues outlined above.

Secondly, for the further study of loanwords in the context of Indonesian-Dutch language contact and colonial lexicography, what we really need is a comprehensive historical-critical and etymological dictionary of Indies Dutch and its varieties which can hold its own against the Anglo-Indian Hobson-Jobson dictionary, Prick van Wely (1910) and Jones (2007).

Third and last but certainly not least, we note that the scholarly basis on which we currently have to pursue our investigations is still rather limited. We do have the stimulating articles by De Vries, Van den Toorn, Van Rheeden, Van der Sijs, Giesbers and 't Hart as well as the dissertations by Groeneboer, Tahitu and Kortendick, but we do not yet have what was envisaged already before the war by De Geus and Van Dam (1935): a comprehensive scholarly monograph (à la Lanly, 1970), giving a solid and systematic contact-linguistic analysis and description of the mixed features of Indies Dutch and its varieties.

\section{References}

Bast, Truska

2010 En zij die na ons komen [And those who come after us]. The Hague: NIDI.

Castles, Lance

1967 The Ethnic Profile of Djakarta. Indonesia 1: 153-204.

Chaer, Abdul

1982 Kamus Dialek Jakarta [Jakarta Dialect Dictionary]. Jakarta: Nusa Indah. 
Cleintuar, Guus L.

1971 Indische Nederlanders. Een ontheemde bevolkingsgroep zonder toekomstbeeld [Indies Dutch people: a homeless group without perspective]. The Hague: Tong Tong.

Daman, Johannes A.

1941 Vijftig jaren van strijd 1891-1941. Gedenkschrift [Fifty Years of Struggle 1891-1941. A Memoir]. Purmerend: Muusses.

De Braconier, Ae

1919 Pauperisme [Pauperism]. In: D. G. Stibbe (ed.), Encyclopaedie van Nederlandsch-Indië. Volume 3: N-Soemba, 366-368. The Hague/Leiden: Nijhoff/Brill.

De Geus, Ae and Je J. M. van Dam

1935 Indische fouten [Indies errors]. Batavia: Visser.

De Gruiter, Victor E.

1990 Het Javindo, de verboden taal [Javindo, the forbidden language]. The Hague: Moesson.

De Gruiter, Victor Miel

1994 Javindo. A contact-language in pre-war Semarang. In: Peter Bakker and Maarten Mous (eds.), Mixed Languages. 15 Case Studies in Language Intertwining, 151-159. Dordrecht: Foris.

De Swaan, Abram

2001 Words of the World. The Global Language System. Cambridge: Polity.

De Vries, Jan W.

1976 De Depokkers: Geschiedenis, sociale structuur en taalgebruik van een geïsoleerde gemeenschap [Depok people: history, social structure and language use of an isolated community]. Bijdragen Taal-, Land-en Volkenkunde 132(2-3): 228-248.

De Vries, Jan W.

1989 Travestieten in Jakarta. Het Nederlands als geheimtaal [Transvestites in Jakarta: Dutch as a secret language]. Ons Erfdeel 32: 717-722.

De Vries, Jan W.

1994a Petjoh en Javindo als mengtalen: weglating van topic [Petjoh and Javindo as mixed languages: topic-drop]. In: Stanislaw Predota (ed.), Handelingen Regionaal Colloquium Neerlandicum, Wroclaw 1993, 321-326. Wroclaw: Wydawnictwo Uniwersytetu Wrocawskiego.

De Vries, Jan W.

1994b The Language of the Indo-Dutch. In: Martinus A. Bakker and Beverly H. Morrison (eds.), Studies in Netherlandic Culture and Literature, 213-226. Lanham, MD: University Press of America.

De Vries, Jan W.

1997 Verbal morphology in Javindo and Pecok. In: Cecilia Odé and Wim Stokhof (eds.), Proceedings of the seventh International Conference on Austronesian Linguistics [ICAL], 351-359. Amsterdam: Rodopi.

De Vries, Jan W.

2005 Indisch-Nederlands [Indies Dutch]. In: Nicoline van der Sijs (ed.), Wereldnederlands. Oude en jonge variëteiten van het Nederlands, 59-78. The Hague: Sdu.

Den Besten, Hans

1992 De makke van de etymologie van koloniale woorden in het Nederlands [The conundrum of the etymology of colonial words in Dutch]. In: Jaarboek van de Stichting Instituut voor Nederlandse Lexicologie 1991, 52-82. Leiden: INL.

Den Besten, Hans and Frans Hinskens

2005 Diversificatie van het Nederlands door Taalcontact [Diversification of the Dutch language through language contact]. Nederlandse Taalkunde 10: 283-309.

Giesbers, Herman

1995a Dutch-Indonesian language mixing in Jakarta. In: Marcel den Dikken and Kees Hengeveld (eds.), Linguistics in the Netherlands 1995, 89-100. Amsterdam: Benjamins. 
Giesbers, Herman

1995b Mijn tetangga bilang erreg mooi! Dutch-Indonesian code-switching and bilingual speech production models. Summer School in Codeswitching and Language Contact, 81-93. Leeuwarden: Fryske Akademy.

Giesbers, Herman

1996 Drietalig en bidialectaal kodewisselen [Trilingual and bidialectal code-switching]. In: Roeland van Hout and Joep Kruijsen (eds.), Taalvariaties, 85-98. Dordrecht: Foris.

Giesbers, Herman

1997 Dutch in Indonesia: language attrition or language contact? In: Jetske Klatter-Folmer and Sjaak Kroon (eds.), Dutch overseas. Studies in maintenance and loss of Dutch as an immigrant language, 163-180. Tilburg: Tilburg University Press.

Groeneboer, Kees (ed.)

1997 Koloniale taalpolitiek in Oost en West. Nederlands-Indië, Suriname, Nederlandse Antillen, Aruba [Colonial language policy in East and West. The Netherlands Indies, Surinam, the Dutch Antilles, Aruba]. Amsterdam: Amsterdam University Press.

Groeneboer, Kees

1998a Gateway to the West. The Dutch Language in Colonial Indonesia 1600-1950. A History of Language Policy. Amsterdam: Amsterdam University Press.

Groeneboer, Kees

1998b Westerse koloniale taalpolitiek in Azië: het Nederlands, Portugees, Spaans, Engels en Frans in vergelijkend perspectief [Western colonial language policy in Asia: Dutch, Portuguese, Spanish, English and French in comparative perspective]. Mededelingen $K N A W$, Afdeling Letterkunde, Nieuwe Reeks, Deel 61(2): 5-27.

Grijns, Cornelius D.

1991 Jakarta Malay. A multidimensional approach to spatial variation. 2 Vols. Leiden: Universiteit Leiden.

Grijns, Cornelius D.

1998 Between brackets: On "vocabulary building" in Batavia circa 1930. In: Mark Janse (ed.), Productivity and Creativity. Studies in General and Descriptive Linguistics in Honor of E. M. Uhlenbeck, 297-315. Berlin: Mouton de Gruyter.

Jedamski, Doris

1997 De taalpolitiek van de Balai Poestaka [Balai Poestaka's language policy]. In: Kees Groeneboer (ed.), Koloniale taalpolitiek in Oost en West, 159-186.

Jones, Russell (ed.)

2007 Loan-words in Indonesian and Malay. Leiden: KITLV.

Kalff, Samuel

1915 Een doode taal in Indië [A dead language in the East Indies]. Baarn: Hollandia.

Kalff, Samuel

1920 Koloniale idiomen [Colonial idioms]. De Nieuwe taalgids 14: 88-98, 133-141.

Kortendick, Oliver

1996 Indische Niederländer und Tante Lien. Eine Strategie zur Konstruktion ethnischer Identität [Indies Dutch people and Tante Lien: A Strategy for the construction of an ethnic identity]. URL: <http://lucy.ukc.ac.uk/lien>.

Kousbroek, Rudy

1992 Een stervende taal [A dying language]. In: Rudy Kousbroek (ed.), Het Oostindisch kampsyndroom [An East-Indies Camp Syndrome], 216-218. Amsterdam: Meulenhoff.

Lanly, André

1970 Le Français d'Afrique du Nord. Étude linguistique [North African French. A linguistic study]. Paris /Montréal: Bordas.

Maier, Henk

1997 Nederlands-Indië en het Maleis [The Netherlands Indies and the Malay language]. In: Kees Groeneboer (ed.), Koloniale taalpolitiek in Oost en West, 13-54. Amsterdam: Amsterdam University Press. 
Matras, Yaron

2009 Language Contact. Cambridge: Cambridge University Press

Mingaars, Peter, Jaap Heij, Maudy Smith and Pim Posthumus (eds.)

2005 Indisch Lexicon. Indische woorden in de Nederlandse Literatuur [Lexicon of the Indies. Indies words in Dutch literature]. 't Goy-Houten: HES \& De Graaf.

Moeimam, Susi and Hein Steinhauer

2004 Nederlands-Indonesisch woordenboek [Dutch-Indonesian Dictionary]. Leiden: KITLV.

Muhajir

1984 Morfologi Dialek Jakarta. Afiksasi dan reduplikasi [The morphology of the Jakarta dialect. Affixation and reduplication]. Jakarta: Djambatan.

Nieuwenhuis, Gerrit $\mathbf{J}$.

1930 Het Nederlandsch in Indië: Een bronnenboek voor het onderwijs in de nieuwe richting [The Dutch language in the East Indies. A source book for teaching in the new direction]. Groningen/Batavia: Wolters.

Oostindie, Gert

2010 Postkoloniaal Nederland. Vijfenzestig jaar vergeten, herdenken, verdringen [Postcolonial Netherlands. Sixty Five Years of Forgetting, Commemoration, Repression]. Amsterdam: Bert Bakker.

Prick van Wely, Franciscus P. H.

1906 Neerlands taal in 't verre Oosten. Eene bijdrage tot de kennis en de historie van het Hollandsch in Indië [Netherlands language in the Far East. A contribution to knowledge and history of the Dutch language in the East Indies]. Semarang-Soerabaia: Van Dorp.

Prick van Wely, Franciscus P. H.

1910 Viertalig Aanvullend Hulpwoordenboek voor Groot-Nederland. Vermeerderd met door Prof. H. Kern herzien etymologisch aanhangsel [Quadrilingual supplementary dictionary for the Greater Netherlands. Augmented by an etymological supplement edited by prof. $\mathrm{H}$. Kern]. Weltevreden: Visser.

Riyanto, Sugeng

1996 Het ontstaan en de structuur van het Petjoek [Origin and structure of Petjoh]. In: Setiawati Darmojuwono, Lilie Suratminto and Kees Groeneboer (eds.), Duapuluh Lima Tahun Studi Belanda di Indonesia/Vijfentwintig jaar studie Nederlands in Indonesië [Twenty Five Years of Dutch Studies in Indonesia], 409-418. Depok: Fakultas Sastra Universitas Indonesia.

Robinson, Tjalie

1975 Ik en Bentiet [Me and Bentiet]. The Hague: Tong Tong.

Salverda, Reinier

1994a Indisch Nederlands in het Batavia van de jaren dertig. De roman "Goena Goena" van Ceasar Kijdsmeir [Indies Dutch in 1930s Batavia. The novel "Goena Goena” by Ceasar Kijdsmeir]. Indische Letteren 9(1): 29-43.

Salverda, Reinier

1994b Between Dutch and Indonesian. Some Observations on Indo-Dutch in Pre-War Batavia. In: Liberty P Sihombing et al. (eds.), Bahasawan Cendekia. Seuntai karangan untuk Anton M. Moeliono [An accomplished scholar of languages: a bouquet of essays for Anton Moeliono], 356-380. Jakarta: Intermasa.

Salverda, Reinier

1997 Mengsyntaxis: Tjalie Robinsons "Piekerans van een straatslijper" in contactlinguistisch perspectief [Mixed syntax: a contact linguistics perspective on Tjalie Robinsons "Piekerans van een straatslijper']. In: Wim De Geest (ed.), Recente Studies in de Contactlinguistiek, 97-105. Bonn: Dümmler.

Salverda, Reinier

2009 Doing Justice in a Plural Society: A Postcolonial Perspective on Dutch Law and Other Legal Traditions in the Indonesian Archipelago, 1600-Present. Dutch Crossing 33(2): $152-170$. 
Sneddon, James

2003 The Indonesian Language. Its history and role in modern society. Sydney: UNSW Press.

Tadmor, Uri

2007 Grammatical borrowing in Indonesian. In: Yaron Matras and Jeanette Sakel (eds.), Grammatical borrowing in cross-linguistic perspective, 301-328. Berlin: Mouton de Gruyter.

't Hart, Martin

1998 Piekeren over betekenisveranderingen bij Noesantarische Leenwoorden [Thinking about semantic changes in loanwords from the Indonesian archipelago]. In: Hugo Brems, Gerard Elshout, Anne M. Musschoot and Roel Vismans (eds.), Nederlands tweehonderd jaar later. Handelingen Dertiende Colloquium Neerlandicum [The Dutch language two hundred years later. Proceedings of the Thirteenth Dutch Studies Conference], 487-506. Woubrugge: IVN.

't Hart, Martin

2001 Maleise leenwoorden op internet [Malay loanwords on the internet]. In: Yati Suhardi, Munif Yusuf and Kees Groeneboer (eds.), Tiga Puluh Tahun Studi Belanda di Indonesia. Dertig Jaar Studie Nederlands in Indonesië [Thirty Years of Dutch Studies in Indonesia], 35-44. Depok: Fakultas Sastra Universitas Indonesia.

Tahitu, Bert

1989 Melaju Sini. Het Maleis van Molukse jongeren in Nederland [Melaju Sini: the Malay language of young Moluccans in the Netherlands]. Ph.D. thesis, Universiteit Leiden.

Trask, Larry

2000 The Dictionary of Historical and Comparative Linguistics. Edinburgh: Edinburgh University Press.

Trudgill, Peter

1986 Koinéization in Colonial English. In: Peter Trudgill (ed.), Dialects in Contact, 127-161. London: Basil Blackwell.

Twain, Mark

1897 More Tramps Abroad. London: Chatto and Windus.

Van Bree, Cor and Jan W. de Vries

1997 Netherlands. In: Hans Goebl, Peter Nelde and Zdenek Starý (eds.), Contact Linguistics. An International Handbook of Contemporary Research. Vol. 2, 1143-1152. (Handbooks of Linguistics and Communication Sciences 12.2.) Berlin/New York: Mouton de Gruyter.

Van den Toorn, Maarten C.

1957 De taal van de Indische Nederlanders [The language of the Indies Dutch people]. De nieuwe taalgids 50: 218-226.

Van den Toorn, Maarten C.

1995 Couperus en het Indisch-Nederlands [Couperus and Indies Dutch]. De nieuwe taalgids 88(1): $1-8$.

Van der Sijs, Nicoline

2005 Invloed van het Indonesisch [The influence of the Indonesian language]. In: Van der Sijs, Nicoline (ed.), Groot Van Dale Leenwoordenboek. De invloed van andere talen op het Nederlands [Great Van Dale Loanword Dictionary. The influence of other languages on Dutch], 436-451. Utrecht/Antwerp: Van Dale.

Van Ginneken, Jacques

1913 Het Oost-Indisch [East Indies language]. In: Jacques van Ginneken, Handboek der Nederlandsche taal [Handbook of the Dutch language], 300-324. vol. 1. Nijmegen: Malmberg.

Van Leeuwen, Lizzy

2008 Ons Indisch erfgoed. Zestig jaar strijd om cultuur en identiteit [Our Indies Heritage. A sixty year battle for culture and identity]. Amsterdam: Bert Bakker. 


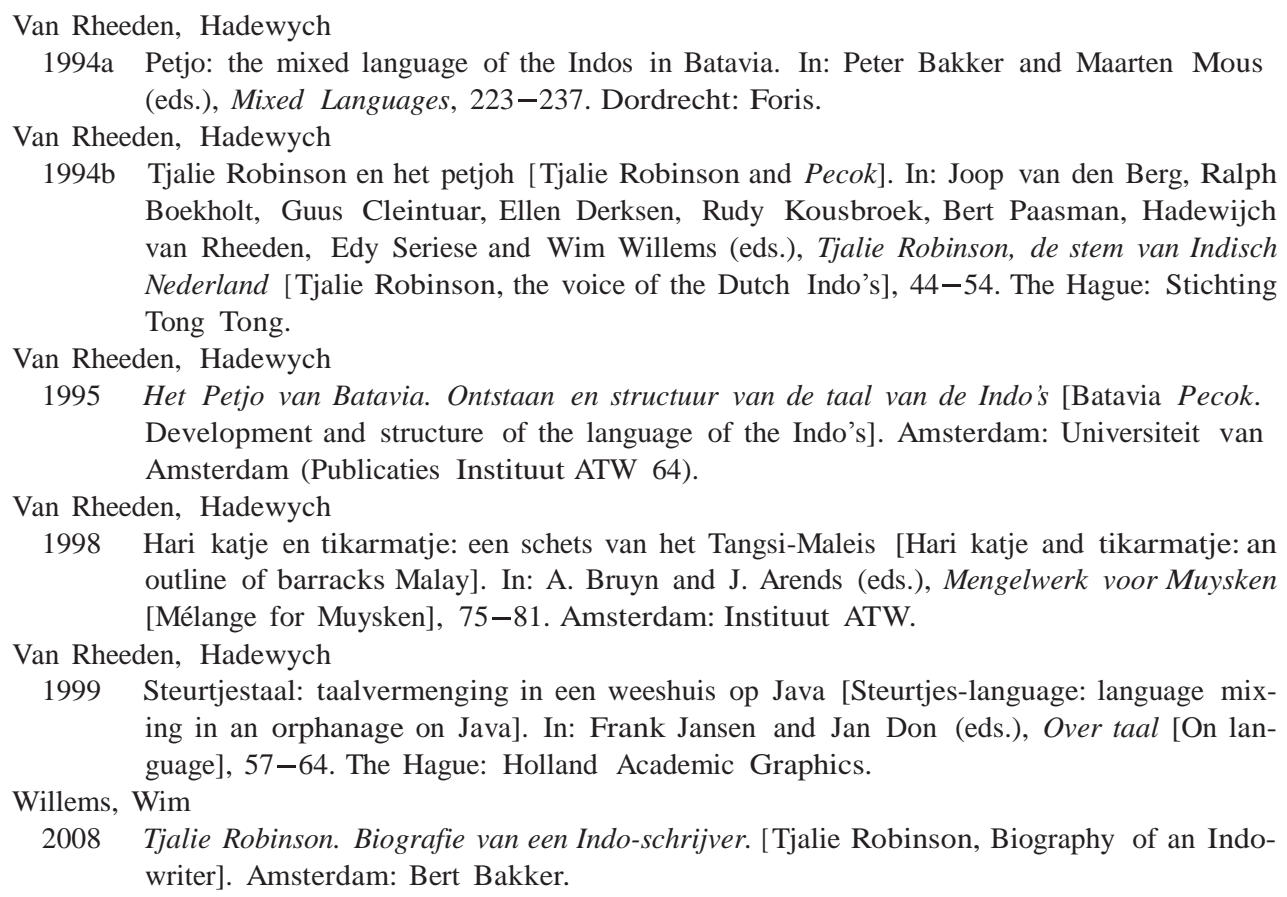

1998 Hari katje en tikarmatje: een schets van het Tangsi-Maleis [Hari katje and tikarmatje: an outline of barracks Malay]. In: A. Bruyn and J. Arends (eds.), Mengelwerk voor Muysken [Mélange for Muysken], 75-81. Amsterdam: Instituut ATW.

Van Rheeden, Hadewych

1999 Steurtjestaal: taalvermenging in een weeshuis op Java [Steurtjes-language: language mixing in an orphanage on Java]. In: Frank Jansen and Jan Don (eds.), Over taal [On language], 57-64. The Hague: Holland Academic Graphics.

Willems, Wim

2008 Tjalie Robinson. Biografie van een Indo-schrijver. [Tjalie Robinson, Biography of an Indowriter]. Amsterdam: Bert Bakker.

Reinier Salverda, London (UK) and Leeuwarden (The Netherlands)

\section{The Dutch Language in the USA}

1. Introduction

2. Publications on Dutch in the USA: An overview

3. Some issues in the study of American Dutch

4. The study of disintegrating languages: On the (non)existence of language norms

5. Further perspectives

6. References

\section{Introduction}

The Dutch language came to the USA during two different waves of immigration, generally referred to as the first and second immigration (Van Hinte 1985). First, Dutch was brought to the New World in the beginning of the seventeenth century. At that time Dutch settlers founded Nieuw Amsterdam, which later became New York. Dutch was spoken in an area which comprises parts of the present states of New York and New Jersey. There can be no doubt that there were still speakers of Dutch around in the first 